\title{
Effects of Salt/Sugar Brine Storage Solutions on Shelf Life of the Salted Atlantic Bonito
}

\author{
Nuray Erkan (D), İdil Can Tunçelli (D), Özkan Özden (1)
}

Cite this article as: Erkan, N., Can Tuncelli, I. \& Ozden, O. (2020). Effects of salt/sugar brine storage solutions on shelf life of the salted atlantic bonito. Aquatic Sciences and Engineering, 35(4), 119-26.

ORCID IDs of the author:

N.E. 0000-0002-0752-8495;

I.C.T. 0000-0002-9999-6658;

Ö.0̈. 0000-0001-8780-480X

Istanbul University, Faculty of Aquatic Sciences, Department of Fisheries and Seafood Processing Technology, Istanbul, Turkey

\section{Submitted:}

08.05.2020

Revision Requested: 30.05.2020

Last Revision Received: 30.05.2020

\section{Accepted:}

10.06.2020

Online published:

17.08.2020

Correspondence:

Nuray Erkan

E-mail:

nurekan@istanbul.edu.tr

(C) Copyright 2020 The Author(s)

Available online at

https://dergipark.org.tr/ase

\begin{abstract}
In this study, Atlantic bonito was prepared as a salted traditional fish product known as Lakerda using the combined techniques of dry salting and brine salting. The product was preserved in brine containing $15 \%$ salt according to the traditional method and was analysed by comparison with $6.5 \%$ salt (Group A) and 6.5\% salt-5\% sugar (Group B) containing brine in cold storage. According to sensory analysis findings, Group A could be safely consumed from cold storage for 7 weeks and Group B for 9 weeks. The international acceptable limit values for analysis findings were not exceeded in both groups. However, the chemical and microbiological analysis results of the samples stored in the salt-sugar containing brine were found to be statistically lower than the salt-containing brine. It is concluded that the application of salt-sugar brine with acceptable results in terms of product safety and sensory properties can be recommended in the preservation of lakerda.
\end{abstract}

Keywords: Lakerda, brine, sugar, salt, shelf life, Atlantic Bonito

\section{INTRODUCTION}

Salting is a traditional fish processing method and one of the preservatives most used in many countries of the world since ancient times, it is widely used with positive technological effects on taste and low cost, all around the world (Giuffrida et al., 2017). Microbial and enzyme activity in seafood can be controlled with reducing water activity by salting, resulting in the extend shelf life of the fisheries products. Salt also increases the texture and taste of the product. Depending on the size and composition of the fish, different salting methods such as dry and brine salting can be used (Horner, 1997; Sen, 2005). Salting of fish may be performed by dry-salting, brining, brine injection, or a combination of these techniques. In the traditional salting process, the water content is usually reduced from approximately $82 \%$ to about $54 \%$ (Oliveira et al., 2012). Dry salting is a method where salt crystals are applied to the flesh and fish are stacked in dry salt. As the salt pene- trates the extracted moisture is allowed to drain away. This method is more preferred for lean fish. In salting, if the water separated from the tissue is allowed to drain it can be identified as "kench (dry) salting" and if this liquid is not allowed to be removed, the term "pickle" can be used (Sen, 2005). The brine water formed by water separated from the tissue should be drained away continuously in kench type dry salting. Especially in semi-dry salting and pickle type salting, there is an essential effect on product maturation by autolysis and proteolytic enzymes and microorganism activity (Horner, 1997). The ripening time required for the formation of the salty fish's characteristic flavour, appearance and texture will vary according to fish species, fish flesh thickness, fat content, and desired degree of curing. Brine salting is the method of preserving fish in a concentrated saturated salt solution. Pickling and brining are advantageous for fatty fish since being immersed in brine, fat is protected from atmospheric oxygen (Sen, 2005). Various factors such 
as fish flesh thickness, composition and concentration of brine, ratio of brine to product and salting time are effective factors for the intramuscular diffusion of salt in this type of salting (Oliveira et al., 2012). It is an advantage to allow the fish to be soaked with brine to give sufficient time for the muscle to absorb a significant amount of salt. This reduces time and increases the weight efficiency of the salting process (Thorarinsdottir et al., 2004; Oliveira et al., 2012).

Salted products are generally defined as traditional fish products in the world and our country. Northern and Southern Europe countries such as Norway, Iceland, Spain and Portugal mostly consume salted cod. Several different species like Gadus morhua, Gadus macrocephalus, and Gadus ogac are used in the production of salted cod (Oliveira et al., 2012). In Sudan, consumers tend to prefer little fat in salted products and mostly use certain lean fish types such as Hydrocynus spp "Kass" (Ahmed et al., 2010). Whereas in South-eastern Europe, mostly in Greece, salted herring, anchovy, and marinade (herring) are widely consumed. Waxed caviar made from mullet roe is also consumed widely in Turkey. There are also some products made with combined processing techniques, such as lakerda which is a traditional salted fish product very popular in both Turkey and Greece, prepared from both dry salting and brining. One of the salted products prepared by applying combined techniques is salted cod. In salted cod, unlike lakerda, brine salting is applied first and then dry salting is applied. The salting process is followed by packaging and storage.

Nowadays, this type of traditional product should be developed in accordance with consumer taste and aroma demands. With the changes in dietary habits, consumers tend to prefer appropriate, quality and safe foods such as salt and sugar-processed seafood. These types of products are considered as a different, attractive and promising alternative to processed traditional seafood products (Lyu et al., 2017).

Like the effect of salt, sugar use extends the storage time of products by reducing water activity in foods (Zhang et al., 2015). However, there is little information in the literature on how using salt and sugar together affects changes in the quality or shelf life of fishes.

In this study, the effect of salt and salt-sugar containing brine on the quality and shelf life of seafood made from Atlantic bonito (Sarda sarda, Bloch, 1793) preserved in brine was examined.

\section{MATERIALS AND METHODS}

\section{Materials}

Salted fish was prepared from 14 pieces of Atlantic bonito (Sarda sarda) obtained from İstanbul Gürpınar Wholesale Fish Market (Turkey). The average length and weight of the fish was 39.69 \pm 2.04 $\mathrm{cm}$ and $995.60 \pm 133.51 \mathrm{~g}$, respectively.

\section{Production of salted Atlantic bonito}

Atlantic bonito were brought to the laboratories in two hours with polystyrene boxes in ice. The fish were headed, gutted, their dorsal, caudal, and lateral fins were removed then they were cut into pieces, with a maximum width of $8 \mathrm{~cm}$ (Figure 1). Then their blood clots and bone marrow were completely removed. After this, the fish were dipped in an iced solution containing $2 \%$ salt. The fish were dry salted [fish weight: salt weight (1:1)] for 7 days at $4 \pm 2^{\circ} \mathrm{C}$, brined in a $15 \%$ salt solution, fish to salt solution ratio was $1: 1$, for 13 days at $4 \pm 2^{\circ} \mathrm{C}$. At the end of the ripening process, the fish were divided into two groups: Group A containing 6.5\% salt and Group B containing 6.5\% salt and 5\% sugar. The production process of salted fish is given in Figure 1. The salted fish products were stored in these different storage solutions while being in cold storage at $4 \pm 2^{\circ} \mathrm{C}$. All analytical determinations were done every two weeks to determine the shelf life.

The proximate composition and $\mathrm{pH}$ of the samples were deter-

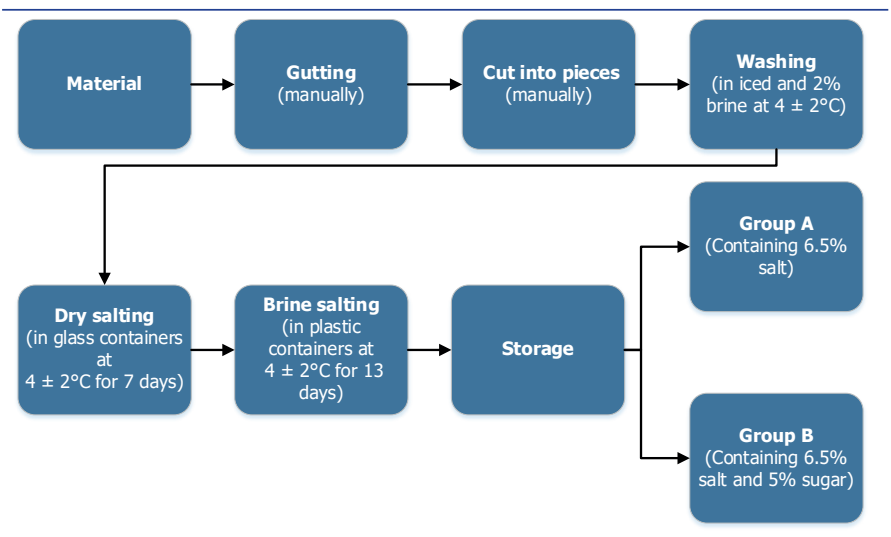

Figure 1. The production process of salted fish prepared from Sarda sarda.

mined throughout the processing steps from raw material until storage. The chemical analysis was determined both in the salted fish flesh and the brine. The microbiological and sensory attributes were analysed in fish flesh throughout the storage.

\section{Proximate composition}

The lipid content (Weilmeier \& Regenstein, 2004), moisture content (Cunniff, 1998), ash content (Cunniff, 1990a) and total crude protein content (Cunniff, 1990b) of the samples were analysed until the ripening in brine process.

\section{$\mathrm{pH}$}

The $\mathrm{pH}$ of the samples was evaluated in raw material through the processing steps until storage solutions part. The $\mathrm{pH}$ was measured at room temperature in homogenates of fish flesh in distilled water (1/10 w/w) (Vyncke, 1981). The monitoring of the $\mathrm{pH}$ was performed using a calibrated WTW-pH-Meter.

\section{Determination of total volatile basic nitrogen (TVB-N)}

Total volatile basic nitrogen (TVB-N) analysis was performed according to Antonacopulous \& Vyncke (1989). For TVB-N in fish flesh, a $10 \mathrm{~g}$ sample was homogenized in an Ultra Turrax (IKA T 25 Basic, Staufen, Germany) with $6 \%$ perchloric acid (90 mL) for 1 minute. The same procedures were applied to the brine for TVB-N, $10 \mathrm{~mL}$ of the brine solutions were stirred with $6 \%$ perchloric acid $(90 \mathrm{~mL}$ ) for 1 minute in an Ultra Turrax. The homogenates were filtered through a filter paper (Whatman No. 1) and alka- 
lized with $\mathrm{NaOH}(20 \%)$ before distillation. After the distillation (with the VELP UDK 140, Milan, Italy) the filtrates were titrated with $0.01 \mathrm{~N} \mathrm{HCl}$ and calculated with the following formula.

$$
T V B-N(m g / 100 g)=\frac{(V 1-V 0) \times 0.14 \times 2 \times 100}{M}
$$

V1: Volume of $0.01 \mathrm{~N} \mathrm{HCl}$ solution (in $\mathrm{mL}$ ) for the sample

V0: Volume of $0.01 \mathrm{~N} \mathrm{HCl}$ solution (in $\mathrm{mL}$ ) for the blank

$\mathrm{M}=$ Weight of the sample in $\mathrm{g}$

\section{Determination of trimethylamine nitrogen (TMA-N)}

TMA-N was determined by the modified method of Erkan \& Özden (2008). Ten grams of homogenized samples were blended with $90 \mathrm{~mL}$ of $7.5 \%$ trichloroacetic acid solution in an Ultra Turrax and filtrated. $4 \mathrm{~mL}$ of the filtered solution was transferred into test tubes and $1 \mathrm{~mL}$ formaldehyde solution (20\%), $10 \mathrm{~mL}$ anhydrous toluene, and $3 \mathrm{~mL} \mathrm{KOH}$ solution were added. The tubes were shaken for 3 minutes and $5 \mathrm{~mL}$ of the top layer was pipetted and transferred into test tubes. $5 \mathrm{~mL}$ picric acid working solution $(0.02 \%)$ was added to the pipetted top layers. The mixed contents were transferred to a spectrophotometric cell and measured in a UV-VIS spectrophotometer at $410 \mathrm{~nm}$ absorbance against the blank. Samples were calculated as $\mathrm{mg} / 100 \mathrm{~g}$ in fish flesh according to the equation of the curve obtained from the standards.

\section{Determination of thiobarbituric acid (TBA)}

The Erkan \& Özden (2008) modified method was used to determine the thiobarbituric acid (TBA) reactive substances. The fish flesh samples were placed in a $50 \mathrm{~mL}$ centrifuge tube and homogenized at high speed for 2 min in Ultra-Turrax with addition of $16 \mathrm{~mL}$ of $5 \%(\mathrm{w} / \mathrm{v})$ TCA solution and $100 \mu \mathrm{L}$ of butylated hydroxytoluene. The mixture was then filtered through a Whatman No. 1 filter paper. The $5 \mathrm{~mL}$ filtrate was mixed with $1 \mathrm{~mL}$ of a $0.01 \mathrm{M}$ aqueous 2-TBA solution. The mixture was heated in a boiling water bath $\left(70-80^{\circ} \mathrm{C}\right)$ for 30 minutes until the pink color was completely formed and then cooled to room temperature. TBA level was measured at $532 \mathrm{~nm}$ in UV-VIS spectrophotometer (Shimadzu Model 1610, Riverwood Drive Columbia, MD).

TBA values were expressed as milligrams of malondialdehyde (MDA)/kilogram of fish flesh. The concentration of MDA was calculated from a standard curve using solutions of the MDA precursor (same molecular weight) 1,1,3,3-tetraethoxy-propane (TEP) into distilled water after the addition of a quantity of TBA solution. The TBA value (mg of MDA/ $\mathrm{kg}$ of fish meat) was obtained by the formula: The concentration of MDA calculated from standard curve $x$ dilution factor/samples weight.

\section{Microbiological analysis}

Samples (25 g) were transferred aseptically to a Stomacher bag containing $225 \mathrm{~mL}$ of $0.1 \%$ peptone water (Merck, 107228) and homogenized for 60 s using a Lab Blender 400, Stomacher at high speed (Stomacher, IUL Instrument, Spain). For microbial count, $0.1 \mathrm{~mL}$ samples of serial dilutions (1:10, diluents, $0.1 \%$ peptone water (Merck, 107228, Darmstadt, Germany) of fish homogenates were spread on the surface of agar plates. Additionally $3.5 \%$ salt was added to agar and peptone. Plate count agar (PCA; Merck 1.05463) was used for psychrotrophic and mesophilic bacteria and incubated at $7^{\circ} \mathrm{C}$ for 10 days. Dichloran Rose Bengal Chloramphenicol (DRBC; Merck 1.00466) agar was used for mold-yeast and incubated at $25^{\circ} \mathrm{C}$ for 5 days. Results are expressed as a logarithm of colony forming units (log cfu) per gram of sample (Baumgart, 1986).

\section{Sensory analysis}

Salt brine and salt-sugar brine fish samples were assessed by 5 experienced panellists on the basis of appearance, taste, odour and texture characteristics using a ten-point descriptive scale, performed under controlled light, temperature and humidity conditions in individual booths. A score of 10.0-9.0 indicated "excellent" quality, a score of 8.9-8.0 "very good" quality, a score of 7.9-6.0 "good" quality, a score of 5.9-4.0 "acceptable" quality and a score below 4.0 indicated "unacceptable" quality (Karl et al., 2001).

\section{Statistical analysis}

Significant differences between the samples were calculated by IBM SPSS Statistics 21 (IBM Corp., USA) using a significance level of $\mathrm{p}<0.05$ by the independent samples $t$-test. Possible differences between mean values of proximate composition results were analysed using ANOVA and when needed, post-hoc comparisons were done using Tukey's test.

\section{RESULTS AND DISCUSSION}

\section{Proximate composition}

The lipid, moisture, ash and total crude protein contents of the fresh, salted and ripenned samples in brine are given in Table 1. The lipid content of the fresh bonito was 32.99\% (Table 1) which is similar to a study by Koral (2006) who reported $38.99 \%$. Çağlak (2009) reported the lipid content of the fresh bonito samples as $23.4 \%$, which is relatively lower. After salting, the amount of nutrient components changed - the amount of protein and ash increased by $6 \%$ and $8 \%$, respectively (Table 1). Ormancı (2013) found similar results to our study in terms of decrease in lipid content after the salting process. At the beginning of the salting process, the meat swells with the entry of salt into the fish meat and the fish meat retains the water in its body. In the main salting process, protein coagulation occurs due to the intensive salt inflow into the fish meat and water leaves the fish muscle through diffusion (Ormancl, 2013). After the ripening period in brine, the moisture content of lakerda was $51.77 \%$ - similar to Ormancı who reported the value as $51.28 \%$. The ratio of nutrient components such as lipid, protein moisture and ash in fish meat can vary de-

Table 1. The lipid, moisture, ash and protein content of the bonito samples (\%).

\begin{tabular}{lccc}
\hline $\begin{array}{l}\text { Proximate } \\
\text { composition }\end{array}$ & $\begin{array}{c}\text { Fresh } \\
\text { bonito }\end{array}$ & $\begin{array}{c}\text { After } \\
\text { salting }\end{array}$ & $\begin{array}{c}\text { After ripen- } \\
\text { ing brine }\end{array}$ \\
\hline Lipid & $32.99 \pm 0.51^{\mathrm{a}}$ & $25.68 \pm 0.52^{\mathrm{b}}$ & $25.11 \pm 0.45^{\mathrm{a}}$ \\
Moisture & $49.97 \pm 0.22^{\mathrm{a}}$ & $42.78 \pm 0.28^{\mathrm{b}}$ & $51.77 \pm 0.07^{\mathrm{c}}$ \\
Ash & $1.05 \pm 0.10^{\mathrm{a}}$ & $9.52 \pm 0.11^{\mathrm{b}}$ & $7.76 \pm 0.04^{\mathrm{c}}$ \\
Protein & $15.94 \pm 0.76^{\mathrm{a}}$ & $21.93 \pm 0.70^{\mathrm{b}}$ & $15.24 \pm 0.49^{\mathrm{b}}$ \\
\hline
\end{tabular}

All values are the mean \pm standard deviation $(n=3)$. Different letters $(a, b, c)$ in the same line indicate significant differences between groups $(p<0.05)$. 
pending on the type of fish, nutrition, reproduction, age and environment (Tülsner, 1994).

\section{$\mathrm{pH}$}

Immediately after capture, the $\mathrm{pH}$ values of the fish were reported between 6.0 and 6.5. Quality of the fish were acceptable up to a $\mathrm{pH}$ of 6.8 but were considered to be spoiled above a $\mathrm{pH}$ of 7.0 as stated in Koral \& Köse (2018). According to the literature data, the $\mathrm{pH}$ value of the raw material is within the freshness limits. As seen in Table 2, it ranged from 5.82 to 6.38 in Group A and from 5.86 to 5.62 in Group B during the 11-week storage period. Ormanci and Colakoglu (2017) reported a decrease in $\mathrm{pH}$ values from 6.38 to 5.94 in lakerda from Atlantic bonito. The $\mathrm{pH}$ decrease in the storage process of our samples is also related to this. These decreases in $\mathrm{pH}$ are explained by the increase in the ionic strength of the solution in the cells (Goulas \& Kontaminas, 2005).

\section{Total volatile basic nitrogen (TVB-N)}

TVB-N production is generally used as an index to assess the preservation of the quality and shelf life of seafood products, and its production is closely related to the activity of spoilage bacteria (Erkan et al., 2009). The European Union set the limits of TVB-N for unprocessed fishery products at 25-35 mg/100 g (EC, 2008). The legal TVB-N limit determined for oily fish (sardines, herring and mackerel) is $20 \mathrm{mg} / 100 \mathrm{~g}$ (Erkan et al., 2009).

Indexes for TVB-N in the fish samples from both Group A, B and their brine solutions are shown in Table 3. During 11 weeks of storage Group A and B did not exceed the limits. However, the TVB-N levels of the Group A brine solution exceeded the limits at the $9^{\text {th }}$ and $11^{\text {th }}$ weeks. TVB-N values of the brine solution of the Group A at $9^{\text {th }}$ and $11^{\text {th }}$ weeks were $23.84 \mathrm{mg} / 100 \mathrm{~g}$ and 27.47 $\mathrm{mg} / 100 \mathrm{~g}$, respectively.

Erkan et al. (2009), found a low TVB-N value in brine stored Atlantic bonito compared to those stored in vacuum packs and oil packed during storage, as a result of which the total volatile basic nitrogenous compounds in flesh are dissolved in the brine. Although small fluctuations were observed, $8.20 \mathrm{mg} / 100 \mathrm{~g}$ was measured in the lakerda packed in brine at the end of the 4 month storage period (Erkan et al., 2009). In this study, as found in Erkan's study (2009), volatile basic compounds formed in the lakerda were transferred to brine solution during storage.

As in the study of Koral and Köse (2018), of the Atlantic bonito samples to which different concentrations (1:3, 1:4, 1:6 fish: salt ratio) were applied, those from dry salting were found to have an increased TVB-N value during storage, thus it was possible to comment on the quality of the product according to TVB-N freshness criteria.

In the later stages of storage, the absence of an increase in TVB-N can be attributed to the $\mathrm{CO}_{2}$ solution in the fish muscle metabolised by lactic acid bacteria. After $\mathrm{CO}_{2}$ absorption, the acidic solution neutralized basic metabolites (ammonia and amine compounds) from fish spoilage and caused the TVB-N to fall slightly. Significantly lower TVB-N values may be associated

Table 2. The changes of $\mathrm{pH}$ values of the salted Atlantic bonito stored in different brine solutions at $4 \pm 2^{\circ} \mathrm{C}$.

\begin{tabular}{|c|c|c|c|c|c|c|c|c|}
\hline Analysis & Raw Material & Group & $1^{\text {st }}$ week & $3^{\text {rd }}$ week & $5^{\text {th }}$ week & $7^{\text {th }}$ week & $9^{\text {th }}$ week & $11^{\text {th }}$ week \\
\hline \multirow{2}{*}{$\mathrm{pH}$} & \multirow{2}{*}{$5.84 \pm 0.01$} & $A$ & $5.82 \pm 0.01^{a}$ & $5.85 \pm 0.01^{a}$ & $5.73 \pm 0.01^{a}$ & $5.34 \pm 0.02^{a}$ & $5.97 \pm 0.01^{a}$ & $6.38 \pm 0.05^{a}$ \\
\hline & & $B$ & $5.86 \pm 0.01^{b}$ & $5.71 \pm 0.02^{b}$ & $5.56 \pm 0.00^{b}$ & $5.16 \pm 0.01^{b}$ & $5.59 \pm 0.01^{b}$ & $5.62 \pm 0.02^{b}$ \\
\hline
\end{tabular}

Table 3. The changes in the values of TVB-N, TMA-N and TBA of salted Atlantic bonito stored in different brine solutions $\left(4 \pm 2^{\circ} \mathrm{C}\right)$.

\begin{tabular}{|c|c|c|c|c|c|c|c|c|}
\hline Analysis & Raw Material & Groups & $1^{\text {st }}$ week & $3^{\text {rd }}$ week & $5^{\text {th }}$ week & $7^{\text {th }}$ week & $9^{\text {th }}$ week & $11^{\text {th }}$ week \\
\hline \multirow{3}{*}{$\begin{array}{l}\text { TVB-N } \\
(\mathrm{mg} / 100 \mathrm{~g})\end{array}$} & \multirow{3}{*}{$6.31 \pm 0.11$} & $A$ & $1.38 \pm 0.06^{a}$ & $1.41 \pm 0.12^{a}$ & $2.79 \pm 0.11^{a}$ & $4.90 \pm 0.10^{a}$ & $8.87 \pm 0.16^{a}$ & $16.49 \pm 0.10^{a}$ \\
\hline & & A (Brine) & $1.12 \pm 0.06^{a}$ & $2.17 \pm 0.04^{a}$ & $4.77 \pm 0.03^{a}$ & $10.36 \pm 0.18^{a}$ & $23.84 \pm 0.03^{a}$ & $27.47 \pm 0.05^{a}$ \\
\hline & & B (Brine) & $0.84 \pm 0.05^{b}$ & $1.34 \pm 0.13^{b}$ & $1.93 \pm 0.04^{b}$ & $2.86 \pm 0.06^{b}$ & $3.55 \pm 0.02^{b}$ & $5.39 \pm 0.03^{b}$ \\
\hline \multirow{3}{*}{$\begin{array}{l}\text { TMA-N } \\
(\mathrm{mg} / 100 \mathrm{~g})\end{array}$} & \multirow{3}{*}{$1.70 \pm 0.18$} & $A$ & $0.63 \pm 0.07^{a}$ & $0.53 \pm 0.18^{a}$ & $0.33 \pm 0.04^{a}$ & $0.31 \pm 0.03^{a}$ & $0.63 \pm 0.02^{a}$ & $0.40 \pm 0.01^{a}$ \\
\hline & & A (Brine) & $0.72 \pm 0.14^{a}$ & $0.69 \pm 0.07^{a}$ & $0.53 \pm 0.05^{a}$ & $0.52 \pm 0.01^{a}$ & $0.94 \pm 0.05^{a}$ & $0.77 \pm 0.05^{\mathrm{a}}$ \\
\hline & & B (Brine) & $0.84 \pm 0.01^{a}$ & $0.64 \pm 0.02^{\mathrm{a}}$ & $0.35 \pm 0.03^{b}$ & $0.33 \pm 0.02^{b}$ & $0.58 \pm 0.01^{b}$ & $0.43 \pm 0.02^{b}$ \\
\hline \multirow{4}{*}{$\begin{array}{l}\text { TBA ( } \mu g \\
\text { MDA/g) }\end{array}$} & \multirow{4}{*}{$0.77 \pm 0.01$} & $A$ & $6.15 \pm 0.30^{a}$ & $4.29 \pm 0.04^{a}$ & $2.45 \pm 0.02^{a}$ & $3.39 \pm 0.02^{\mathrm{a}}$ & $4.29 \pm 0.06^{a}$ & $5.82 \pm 0.08^{a}$ \\
\hline & & A (Brine) & $0.20 \pm 0.03^{a}$ & $0.98 \pm 0.02^{a}$ & $1.82 \pm 0.01^{a}$ & $2.05 \pm 0.03^{a}$ & $2.29 \pm 0.05^{a}$ & $2.39 \pm 0.01^{a}$ \\
\hline & & $B$ & $6.27 \pm 0.03^{a}$ & $5.17 \pm 0.15^{b}$ & $3.74 \pm 0.02^{b}$ & $2.88 \pm 0.02^{b}$ & $2.83 \pm 0.07^{b}$ & $2.73 \pm 0.02^{b}$ \\
\hline & & B (Brine) & $0.79 \pm 0.01^{b}$ & $1.23 \pm 0.01^{b}$ & $2.61 \pm 0.07^{b}$ & $2.35 \pm 0.01^{b}$ & $2.62 \pm 0.03^{b}$ & $2.85 \pm 0.02^{b}$ \\
\hline
\end{tabular}

All values are the mean \pm standard deviation $(n=3)$. Different letters $(a, b)$ in the same column indicate significant differences $(p<0.05)$. The groups were evaluated within themselves $[A, B$ and $A($ Brine $), B($ Brine $)]$. 
with this. As Wang et al. (2016) mentioned in their study, this reduction can be due to the addition of sugar as an energy source to microorganisms. There are also other studies about significant effects of salt and sugar treatment which results in decreasing TVB-N and pH levels (Zhang et al., 2015; Wang et al., 2016; Oin et al., 2017; Li et al., 2018).

\section{Trimethylamine nitrogen (TMA-N)}

The TMA-N values of the salted Atlantic bonito stored in different brine solutions are shown in Table 3. In marine fish, trimethylamine oxide (TMAO), which is reduced by bacterial and enzymatic action to, TMA which is a spoilage product and is one of the main substances that causes stale fishy odor (Koral and Köse, 2018). Sikorski et al. (1990), proposed an acceptable level for TMA of $5 \mathrm{mg} / 100 \mathrm{~g}$.

Similar to the results of the TVB-N analysis, the TMA values, which are volatile nitrogenous compounds, were found to be quite low in this study. The TMA values of the fresh Atlantic bonito was $1,70 \pm 0,18 \mathrm{mg} / 100 \mathrm{~g}$ which indicates the raw material was very good quality. At the beginning of storage, the TMA values were $0.63 \pm 0.07 \mathrm{mg} / 100 \mathrm{~g}$ (Group A) and 0.40 $\pm 0.02 \mathrm{mg} / 100 \mathrm{~g}$ (Group B). The TMA levels of the brine solutions of groups $A$ and $B$ were $0.72 \pm 0.14 \mathrm{mg} / 100 \mathrm{~g}$ and $0.84 \pm 0.01 \mathrm{mg} / 100 \mathrm{~g}$, respectively. After 11 weeks of storage the TMA levels of both groups and their brine did not show any significant increase, nevertheless they were measured at a fairly low levels. It is thought this was caused by the preservative effects of sugar and salt.

Koral and Köse (2018), reported the TMA levels of the group with $1: 3$ salt: fish ratio between 2.28- 3.86 mg/100 g during 12 weeks of storage. Similarly, Erkan et al. (2009) reported levels of TMA of the brine packed lakerda between 3.81-5.67 mg/100 g during 16 weeks of storage (Erkan et al., 2009).

The notable loss of nitrogenous components during brining is related to increased protein solubility in the tissues resulting from increased salt content, proteins and the destruction of these components may result in leaching into the brine (Martinez et al., 2012). However, in the present study, our data shows very low levels of TMA both in flesh and brine which can be explained by solubility of these nitrogenous components.

\section{Thiobarbituric acid (TBA)}

In traditional salted fish products, depending on preference, fatty fish such as mackerel, sardine, anchovies, bonito and lean fish such as cod, meagre can be preferred, but fat oxidation is a major problem in the quality of these products.

Fish are rich in polyunsaturated fatty acids that are very valuable in muscle tissue, food and nutritional physiology, but these fatty acids are easily oxidized in aerobic environments. The first oxidative oxidation products in fish oil tissue are unstable peroxide compounds. Since peroxides are unstable compounds that deteriorate rapidly to other degradation products, measuring the peroxide value is not a good parameter for making accurate determinations about product quality. Peroxides are divided into more stable components called malonaldehydes during oxidation. The TBA value generally shows a steady increase in fish and fish products, as in our study, and a decrease in correlation with changes in acceptable flavor and taste (Selmi et al., 2010).
There are several advantages to brining, such as protection against oxidative degradation (Oliveira et al., 2012). The changes in TBA values, which are indicative of the oxidative degradation rate, are shown in Table 3. The TBA value of the fresh Atlantic bonito was $0.770 \mathrm{mg} \mathrm{MDA} / \mathrm{kg}$. The TBA values of Group A and B were determined as $6.15 \mathrm{mg} \mathrm{MDA} / \mathrm{kg}$ and $6.27 \mathrm{mg} \mathrm{MDA} / \mathrm{kg}$, respectively. At the end of the storage period, the TBA values of groups $A$ and $B$ were determined as $5.82 \mathrm{mg} \mathrm{MDA} / \mathrm{kg}$ and 2.73 $\mathrm{mg} \mathrm{MDA} / \mathrm{kg}$, respectively.

Erkan et al. (2009) reported that brine packed lakerda $1.52 \mathrm{mg}$ MDA $/ \mathrm{kg}$ ) had the lowest TBA values compared to oil packed (3.03 $\mathrm{mg} \mathrm{MDA} / \mathrm{kg}$ fish) and vacuum packed (2.54 mg MDA/kg) groups. This occurs due to the fatty substance of brine-packaged salted fish separates from the product and pass into the brine during the storage. The fat content of the raw material also affects TBA values.

According to Faraji and Lindsay (2005), some sugars exhibit antioxidant activity and suppress oxidation (and therefore oxidative degradation) to some degree. Martinez et al. (2012), investigated the quality of salmon with different salting methods (dry and brine salting) with sugar additions. The dry salted and sugar added group appeared to provide the best results in shelf life analysis at the end of the 45-day storage. In their study, they concluded that sugar can protect the fish meat from oxidative deterioration, which is also consistent with our results.

\section{Microbiological analysis}

The total aerobic plate counts of mesophilic and psychrophilic bacteria are shown in Table 4. The total viable count limit for marine fish species is 7 log cfu/g (ICMSF, 1986). Initial mesophilic aerobic bacteria counts of the Group A and B were 4.07 $\pm 0.35 \mathrm{log} \mathrm{cfu} / \mathrm{g}$ and $3.61 \pm 0.11 \mathrm{log} c f u / g$, respectively. Psychrophilic aerobic bacteria counts of both groups' results were similar to the mesophilic bacteria. At the end of the storage mesophilic and psychrophilic bacteria counts of groups $A$ and $B$ were 4.59, $4.15 \mathrm{log} c f u / g$ and 5.14, $5.05 \mathrm{log}$ $\mathrm{cfu} / \mathrm{g}$, respectively. However, yeast and mould were not found in the products. Similarly Ahmed et al. (2010), reported that the total viable count load in salted Kass was below the limits and no yeastmold was found. Throughout the 11-weeks of storage the bacterial counts of the products did not show a significant change. Both groups were not deteriorated in term of bacterial limit, which could be attributed to the inhibitory effect of salt on spoilage bacteria.

Erkan et al. (2009) reported that the fresh Atlantic bonito and bonito lakerda's initial psychrotrophic bacteria counts were 3.29 $\log \mathrm{cfu} / \mathrm{g}$ and $3.76 \mathrm{log} \mathrm{cfu} / \mathrm{g}$, respectively and brine-packaged samples after 11 weeks of storage has reached to $5.65 \mathrm{log}$ $\mathrm{cfu} / \mathrm{g}$. The differences in the bacterial counts can be explained by the effect of salt and raw material.

Li et al. (2018) studied the quality of the salted and sugar-salted bream and concluded that bream fillets brined with a $1.8 \%$ salt or $1.8 \%$ salt and $0.9 \%$ sugar can delay deterioration and microbial growth. Similarly, Zhang et al. (2015), who studied the quality of carp fillets treated with different concentrations of salt and sugar, indicated that $6.0 \%$ salt intensely restrained the growth of total viable count compared to the other group (treated with $2.0 \%$ salt and $1.0 \%$ sugar). This shows that the ratio of salt and sugar used in 
Table 4. The changes of total mesophilic aerobic and psychrophilic aerobic bacteria counts of salted Atlantic bonito stored in different brine solutions $\left(4 \pm 2^{\circ} \mathrm{C}\right)$.

\begin{tabular}{|c|c|c|c|c|c|c|c|}
\hline & Group & $1^{\text {st }}$ week & $3^{\text {rd }}$ week & $5^{\text {th }}$ week & $7^{\text {th }}$ week & $9^{\text {th }}$ week & $11^{\text {th }}$ week \\
\hline \multirow{2}{*}{$\begin{array}{l}\text { Total Mesophilic } \\
\text { Aerobic Bacteria } \\
\text { (log cfu/g) }\end{array}$} & A & $4.07 \pm 0.35^{a}$ & $5.46 \pm 0.1^{\mathrm{a}}$ & $5.73 \pm 0.25^{a}$ & $4.81 \pm 0.11^{\mathrm{a}}$ & $4.60 \pm 0.35^{\mathrm{a}}$ & $4.59 \pm 0.09^{a}$ \\
\hline & B & $3.61 \pm 0.11^{b}$ & $3.75 \pm 0.12^{b}$ & $4.16 \pm 0.02^{b}$ & $4.27 \pm 0.2^{b}$ & $4.54 \pm 0.07^{\mathrm{a}}$ & $4.15 \pm 0.13^{b}$ \\
\hline \multirow{2}{*}{$\begin{array}{l}\text { Total Psychrophilic } \\
\text { Aerobic Bacteria } \\
\text { (log cfu/g) }\end{array}$} & A & $3.96 \pm 0.14^{\mathrm{a}}$ & $5.12 \pm 0.1^{\mathrm{a}}$ & $5.24 \pm 0.1^{\mathrm{a}}$ & $5.52 \pm 0.5^{a}$ & $5.56 \pm 0.35^{a}$ & $5.15 \pm 0.46^{a}$ \\
\hline & B & $3.71 \pm 0.06^{b}$ & $3.98 \pm 0.12^{b}$ & $4.03 \pm 0.1^{b}$ & $4.58 \pm 0.19^{b}$ & $4.66 \pm 0.16^{b}$ & $5.05 \pm 0.1^{\mathrm{a}}$ \\
\hline $\begin{array}{l}\text { Mold-Yeast } \\
\text { (log cfu/g) }\end{array}$ & $\begin{array}{l}A \\
B\end{array}$ & $\begin{array}{l}\text { n.d. } \\
\text { n.d. }\end{array}$ & $\begin{array}{l}\text { n.d. } \\
\text { n.d. }\end{array}$ & $\begin{array}{l}\text { n.d. } \\
\text { n.d. }\end{array}$ & $\begin{array}{l}\text { n.d. } \\
\text { n.d. }\end{array}$ & $\begin{array}{l}\text { n.d. } \\
\text { n.d. }\end{array}$ & $\begin{array}{l}\text { n.d. } \\
\text { n.d. }\end{array}$ \\
\hline
\end{tabular}

the product is effective in the formation and suppression of microbial activity, which directly affects the overall quality.

\section{Sensory analysis}

The results of sensory analysis are a very important parameter in determining the quality of all processed fish products, including salted seafood products. Sugar treatment promoted the generation of objectionable odours. This phenomenon may be attributed to acidic metabolites produced by certain anaerobic microorganisms; these metabolites were regarded as off-flavour compounds by sensory panellists (Wang et al., 2016).

Ormanci and Colakoglu who studied the nutritional and sensory properties of the lakerda, characterize this traditional salted Atlantic bonito product as whitish-milky coloured, cohesive and soft rubbery textured, salty and sweat-smell odored (Ormanci and Colakoglu, 2015).

Evaluation of different sensory attributes such as appearance, odour, texture, and flavour of salted Atlantic bonito products by the panellists are given in Table 5. Group A, in the $9^{\text {th }}$ week of storage and Group B in the $11^{\text {th }}$ week of storage in terms of odour and flavour was identified as non-consumable by the panellists. The results for sensory components of the samples showed that the products stored in salt-sugar brine had a better overall sensory acceptance value compared to the salt brined group. Sugar treatment suppressed the production of unwanted odours, resulting in a significant effect $(p>0.05)$ on the overall sensory quality. At the end of the storage it was found that the group with sugar addition had higher mean odour-flavour scores than the group with only salt addition. According to Wang et al. (2016), the combination of salt (1.3\%) and sugar (1.0\%) may delay physical, chemical and microbial changes, while preserving other characteristics of flavour and quality. In this study, the changes in total bacteria counts of both groups were not consistent with sensory evaluation results and the products had a longer shelf life according to the microbiological acceptability limit compared with sensory analysis at $4 \pm 2^{\circ} \mathrm{C}$. This is in correlation with Wang et al. (2016). The panellists compared both groups and stated in the comments that Group B $(6.5 \%$ salt $+5 \%$ sugar) had a better overall quality in terms of texture, appearance, and odour. In our study, sensory scores were a more effective quality index, compared with chemical and microbial results, in determining the shelf life of salted and salt-sugared bonito product. In relation to this, other chemical parameters support our overall sensory quality. The low levels of TBA values developed during storage of the salted Atlantic bonito products (Table 3) support

Table 5. The changes in sensorial attributes of the salted Atlantic bonito stored in different brine solutions $\left(4 \pm 2^{\circ} \mathrm{C}\right)$.

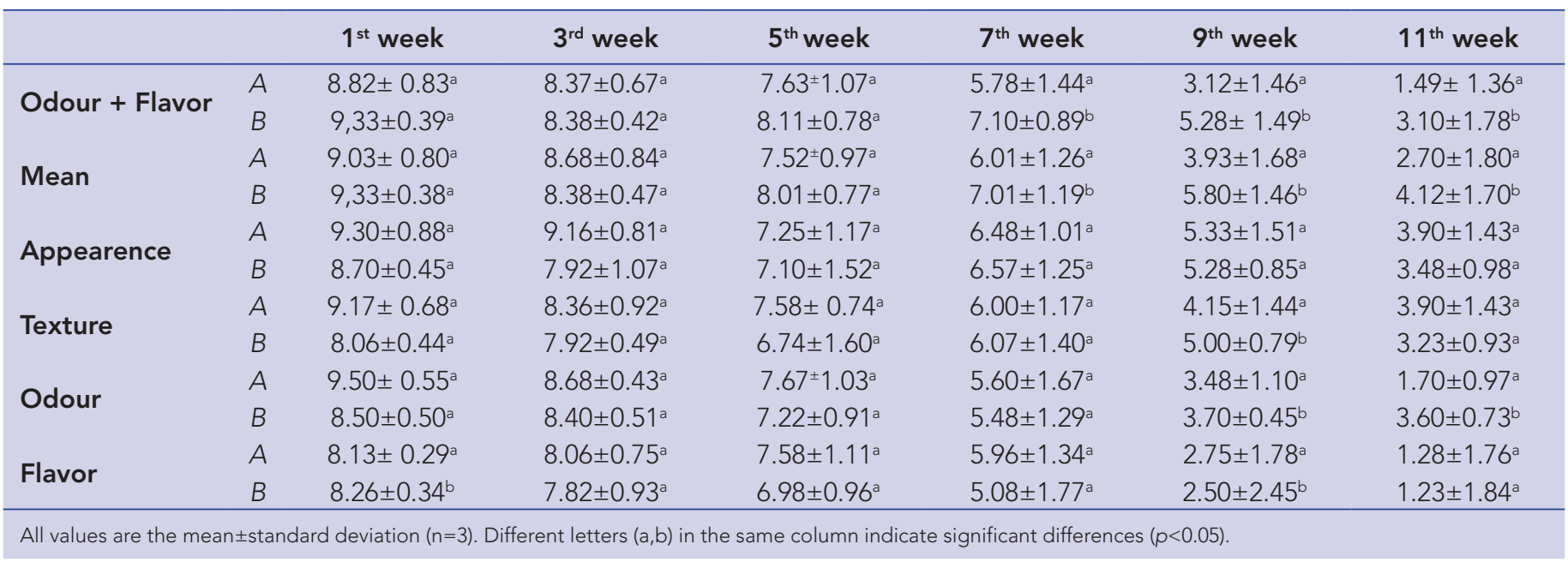


our results in the case that no major rancidity flavour was detected by the panellists. The best strategies to extend shelf life of fish and fish products include the use of natural preservatives. As the effect of enzymes, which break down proteins and fats, the salting process of the compounds in the tissue (proteins, water-soluble vitamins, minerals, and oil) end up breaking up/dissolving into brine (Oliveira et al., 2012).

\section{CONCLUSION}

The results of the analysis showed that there was no difference between the applications in terms of the shelf life of the Atlantic bonito preserved in salt and salt-sugar containing brine. However, chemical and microbiological analysis results were found lower; sensory analysis results were higher in the bonito stored in sugar-containing brine, with this study it was shown that sugar containing brine can be recommended for product safety and sensory properties. Preservation in brine containing salt and sugar gave the lakerda $30 \%$ more shelf life.

Conflict of interests: All authors declare that for this article they have no actual, potential or perceived conflict of interests and that this study does not include any experiments with human or animal subjects.

\section{Ethics committee approval: -}

\section{Funding: -}

\section{Acknowledgments: -}

\section{Disclosure: -}

\section{REFERENCES}

Ahmed, E. O., Ali, M. E., \& Hamed, A. A. (2010). Quality changes of salted Kass (Hydrocynus forskalii) during storage at ambient temperature $\left(37 \pm 1{ }^{\circ} \mathrm{C}\right)$. Pakistan Journal of Nutrition, 9(9), 877881. [CrossRef]

Antonacopulous, N., \& Vyncke, W. (1989). Determination of volatile basic nitrogen in fish: a third collaborative study by the West European Fish Technologists' Association (WEFTA). European Food Research and Technology, 189(4), 309-316. [CrossRef]

Baumgart, J. (1986). Lebensmittel tierischer herkunft, feinkosterzeugnisse, gefrorene, tiefgefrorene und getrocknete lebensmittel, fertiggerichte, hitzekonservierte lebensmittel, speiseeis, zucker, kakao, zuckerwaren, rohmassen. Mikrobiologische Untersuchung von Lebensmitteln, 207. Behr's Verlag, Hamburg, Germany; ISBN:3-922528-91-0.

Cunniff, P. (1990a). Fish and other marine products, Official Method 938.08, Ash of Seafood. In H. K. (Ed.), Official Methods of Analysis of AOAC International (15th ed., p. 868).

Cunniff, P. (1990b). Meat and derived products: Official Method 981.10: Nitrojen in Meat, Kjeldahl Method. In H. K. (Ed.), Official Methods of Analysis of AOAC International (15th ed., p. 937). Virginia, USA: Association of Official Analytical Chemists, Inc.

Cunniff, P. (1998). Official Method 980.46 Moisture in Meat. In Official Methods of Analysis of AOAC International (16th ed.).

Çağlak, E. (2009). Modifiye atmosfer paketleme uygulanan sübye, kara midye ve lakerdanın buzdolabı şartlarında bazı kalite kriterlerinin incelenmesi, Ege Üniversitesi Fen Bilimleri Enstitüsü, İzmir, Türkiye.

Erkan, N. \& Özden, Ö. (2008). Quality assessment of whole and gutted sardines (Sardina pilchardus) stored in ice, International Journal of Food Science \& Technology, 43(9), 1549-1559. [CrossRef]
Erkan, N., Tosun, Ş. Y., Ucok Alakavuk, D. \& Ulusoy, Ş. (2009). Keeping quality of different packaged salted atlantic bonito "lakerda.", Journal of Food Biochemistry, 33(5), 728-744. [CrossRef]

European Commission. (2008). Commission Regulation (EC) No 1022/2008 of 17 October 2008 amending Regulation (EC) No 2074/2005 as regards the total volatile basic nitrogen (TVB-N) limits, (1022), 18-20. Retrieved from https://www.fsai.ie/uploadedFiles/Reg1022_2008.pdf

Faraji, H., \& Lindsay, R. C. (2005). Antioxidant protection of bulk fish oils by dispersed sugars and polyhydric alcohols. Journal of Agricultural and Food Chemistry, 53(3), 736-744. [CrossRef]

Giuffrida, A., Giarratana, F., Valenti, D., Muscolino, D., Parisi, R., Parco, A., Marotta, S., Ziino, G. \& Panebianco, A. (2017). A new approach to predict the fish fillet shelf-life in presence of natural preservative agents. Italian Journal of Food Safety, 6(2). 88-92. [CrossRef]

Goulas, A. E., \& Kontominas, M. G. (2005). Effect of salting and smokingmethod on the keeping quality of chub mackerel (Scomber japonicus): Biochemical and sensory attributes. Food Chemistry, 93(3), 511-520. [CrossRef]

Horner, W. F. A. (1997). Preservation of fish by curing (drying, salting and smoking), in: Hall, G. M. (Eds.), Fish Processing Technology. Springer, Boston, MA., pp. 32-73. [CrossRef]

ICMSF. (1986). Part II. Specific proposals for sampling and sampling plans. Microorganisms in Foods 2: Sampling for Microbiological Analysis: Principles and Specific Applications. [CrossRef]

Karl, H., Meyer, C., \& Münkner, W. (2001). Vergleichende Eislagerung von ausgenommenen und unausgenommenen Schleien. Informationen Für Die Fischwirtschaft Aus Der Fischereiforschung, 48(3), 139-143.

Koral, S. (2006). Taze ve tütsülenmiş kefal (Mugil so-iuy, Basilewski,1855) ve palamut (Sarda sarda, Bloch, 1838) balıklarının oda ve buzdolabı koşullarındaki kalite değişimlerinin belirlenmesi, Karadeniz Teknik Üniversitesi Fen Bilimleri Enstitüsü, Trabzon, Türkiye.

Koral, S., \& Köse, S. (2018). The Effect of Using Frozen Raw Material and Different Salt Ratios on the Quality Changes of Dry Salted Atlantic Bonito (Lakerda) At Two Storage Conditions. Food Health, 4: 213230. [CrossRef]

Li, Y., Lv, Y., Zhang, J., Fang, Y., Feng , L. \& Luo, Y. (2018). Changes in Quality and Microbial Succession of Lightly Salted and Sugar-Salted Blunt Snout Bream (Megalobrama amblycephala) Fillets Stored at $4^{\circ} \mathrm{C}$. Journal of Food Protection, 81(8), 1293-1303. [CrossRef]

Lyu, J., Li, Q., Zhang, L., Zhang, J., Dong, Z., Feng, L., \& Luo, Y. (2017). Changes in quality of rainbow trout (Oncorhynchus mykiss) fillets preserved with salt and sugar at low concentrations and stored at $4^{\circ} \mathrm{C}$. International Journal of Food Properties, 20(10), 2286-2298. [CrossRef]

Martinez, O., Salmerón, J., Guillén, M. D., Pin, C., \& Casas, C. (2012). Physicochemical, sensorial and textural characteristics of liquidsmoked salmon (Salmo salar) as affected by salting treatment and sugar addition. International journal of Food Science \& Technology, 47(5), 1086-1096. [CrossRef]

Oliveira, H., Pedro, S., Nunes, M. L., Costa, R., \& Vaz-Pires, P. (2012). Processing of Salted Cod (Gadus spp.): A Review. Comprehensive Reviews In Food Science and Food Safety, 11(6), 546-564. [CrossRef]

Ormancı, H. B. (2013). Palamut (Sarda sarda) lakerdasının olgunlaşması süresince serbest amino asit ve biyojen amin oluşumunun ürün kalitesine etkileri, Çanakkale Onsekiz Mart Üniversitesi Fen Bilimleri Enstitüsü, Çanakkale, Türkiye.

Ormanci, H. B. \& Colakoglu, F. A. (2015). Nutritional and sensory properties of salted fish product, lakerda. Cogent Food \& Agriculture, 1(1),1-13. [CrossRef]

Ormanci, H. B., \& Arik Colakoglu, F. (2017). Changes in Biogenic Amines Levels of Lakerda (Salted Atlantic Bonito) During Ripening at Different Temperatures. Journal of Food Processing and Preservation, 41(1), e12736. [CrossRef]

Qin, N., Zhang, Y., \& Luo, Y. (2017). Effects of Adding Salt and Sugar on the Quality and IMP-Related Enzyme Activity of Grass Carp 
(Ctebopharyngodon idellus) Fillets During $0^{\circ} \mathrm{C}$ Storage. Journal of Food Processing and Preservation, 41(2), e12844. [CrossRef]

Selmi, S., Bouriga, N., Cherif, M., Toujani, M., \& Trabelsi, M. (2010). Effects of drying process on biochemical and microbiological quality of silverside (fish) Atherina lagunae. International Journal of Food Science \& Technology, 45(6), 1161-1168. [CrossRef]

Sen, D. P. (2005). Traditional salted and dried fish products, in:Sen, D.P. (Eds.) Advances in fish processing technology, Allied Publishers Pvt. Ltd., pp. 261-267.

Sikorski, Z. E., Kolakowska, A., \& Burt, J. R. (1990). Resources Nutritional Composition and Preservation. Pp. 55-75. In: Post harvest biochemical and microbial changes seafood (edited by Z.E. Sikorski). CRC Press-Inc., Boca Raton, FL.

Thorarinsdottir, K. A., Arason, S., Bogason, S. G., \& Kristbergsson, K. (2004). The effects of various salt concentrations during brine curing of cod (Gadus morhua). International Journal of Food Science \& Technology, 39(1), 79-89. [CrossRef]

Tülsner, M. (1994). Fischverarbeitung. 1. Rohstoffeigenschaften von Fisch und Grundlagen der Verarbeitungsprozesse. Behr.

Wang, Z., Fan, H., Chen, J., Luo, Y., \& Chen, K. (2016). Effect of Sugar on the Changes in Quality of Lightly Salted Grass Carp (Ctenopharyngodon idellus) Fillets under Vacuum Packaging at $4^{\circ} \mathrm{C}$. Journal of Food Protection, 79(3), 468-476. [CrossRef]

Vyncke, W. (1981). pH of fish muscle comparison of methods. Copenhagen, Denmark.

Zhang, Y., Qin, N., Luo, Y., \& Shen, H. (2015). Effects of different concentrations of salt and sugar on biogenic amines and quality changes of carp (Cyprinus carpio) during chilled storage. Journal of the Science of Food and Agriculture, 95(6), 1157-1162. [CrossRef] 